Sylvester, P.J., Souders, A.K., and Liu, R., 2022, Significance of U-Pb detrital zircon geochronology for mudstone provenance: Geology, v. 50, https://doi.org/10.1130/G49684.1

\title{
Significance of U-Pb Detrital Zircon Geochronology for
}

\author{
Mudstone Provenance
}

\section{Supplementary Material}

\author{
Paul J. Sylvester ${ }^{1}$, A. Kate Souders ${ }^{1,2}$, and Rui Liu ${ }^{1,3}$ \\ ${ }^{1}$ Department of Geosciences, Texas Tech University, Lubbock, TX 79409-1053 USA \\ ${ }^{2}$ U.S. Geological Survey, Denver, CO 80225 USA \\ ${ }^{3}$ University of New Mexico, Albuquerque NM 87131-0001 USA
}

\section{Table of Contents}

List of Laramide volcanic and shallow intrusive centers and detrital zircons shown in Figure 1 Sample Preparation

SEM and LA-ICP-MS Analysis

Data Repository References

Figures:

Figure S1. Representative BSE images of detrital zircon

Figure S2. Wetherill Concordia diagrams for detrital zircon in Pierre Shale and Trinidad Sandstone

Figure S3. Wetherill Concordia diagrams for zircon reference materials - 20-micron spots Figure S4. Wetherill Concordia diagrams for zircon reference materials - 12-micron spots Figure S5. Th/U plot for ca. 1690 Ma detrital zircon grains

Tables:

Table S1. SEM and LA-ICP-MS metadata Tables S2 - S5. U-Pb detrital zircon data for Pierre Shale and Trinidad Sandstone Table S6. U-Pb zircon reference material data - 20-micron spots Table S7. U-Pb zircon reference material data - 12-micron spots 


\section{List of Laramide volcanic-shallow intrusive centers/detrital zircons shown in Figure 1}

1 - $73 \mathrm{Ma}$ for the diorite dike of Sleeping Ute Mountain, Colorado (Gonzales, 2015)

2 - $68 \mathrm{Ma}$ for the granodiorite-diorite porphyry stock of Hermosa Peak, Colorado (Gonzales, 2015)

3 - 69-65 Ma for the granite-diorite porphyry sill of Coal Bank Pass, Colorado (Gonzales, 2015)

4 - $70 \mathrm{Ma}$ for the diorite stock of La Plata Mountains 'Notch', Colorado (Gonzales, 2015)

5 - Cretaceous McDermott Formation with major 70 Ma detrital zircon age peak, Colorado (Pecha et al., 2018)

6 - Cretaceous Kirtland Formation with major 75 Ma detrital zircon age peak, New Mexico (Pecha et al., 2018)

7 - 75-73 Ma ash-fall tuffs of McRae Formation, Love Ranch Basin, New Mexico (Amato et al., 2017)

8 - 75 Ma monzonite porphyry stock and dacite sill of Twin Peaks, Burro Mountains, New Mexico (Amato et al., 2017).

9 - 73-70 Ma ash-fall tuffs of Ringbone/Skunk Ranch and sandstone of the Cretaceous Ringbone Formation with major 73 Ma detrital zircon age peak, Little Hatchet Mts, New Mexico (Clinkscales and Lawton., 2015)

10 - 73 Ma andesite, southern Winchester Mountains, Arizona (Mizer, 2018)

11 - 76 Ma andesite of Bronco Volcanics and Uncle Sam Tuff, 75 Ma dacite porphyry and 73

Ma Schieffelin granodiorite, Tombstone mining district, Arizona (Mizer, 2018)

12 - 75 Ma Granite Peak stock, Whetstone Mountains, Arizona (Mizer, 2018)

13 - 75 Ma granodiorite, quartz diorite and felsic dikes, Cerro Colorado mining district, Arizona (Mizer, 2018)

14 - 75 Ma El Tiro granite and dacite porphyry, Silver Bell mining district, Arizona (Mizer, 2018)

15 - 74 Ma Williamson Canyon Volcanics, Banner mining district, Arizona (Mizer, 2018) 16 - 73 Ma Concentrator Volcanics, Ajo mining district, Arizona (Mizer, 2018)

\section{Sample Preparation}

Hand-sized samples of Pierre Shale and Trinidad Sandstone were crushed and pulverized to less than mm-sized pieces and washed to remove the finest clays. Based on observed sizes of heavy minerals in the crushed material, the sandstone was sieved into $63-125 \mu \mathrm{m}$ and $20-63$ $\mu \mathrm{m}$ fractions and shale into a $20-63 \mu \mathrm{m}$ fraction. Detrital zircon and other heavy minerals were separated from the less dense minerals in each of the sieved fractions using Lithium Metatungstate (LMT) heavy liquid adjusted to a density of $2.9 \mathrm{~g} / \mathrm{cc}$. The heavy mineral separates were mounted randomly in $25 \mathrm{~mm}$ epoxy rounds, without pre-screening based on magnetic susceptibility, shape or color, which can bias detrital zircon age populations (Sircombe and 
Stern, 2002; Sláma and Košler, 2012; Markwitz et al., 2017). In addition, the separates were mounted as monolayers so that polishing intersected the central portion of each grain, allowing meaningful comparisons of two-dimensional size measurements between different grains (Sylvester, 2012). Thus, the heavy mineral separates provided a grain mount for each of the coarse (TSC) and fine (TSF) heavy mineral fractions of the Trinidad Sandstone and another mount for the heavy mineral fraction of the Pierre Shale (PSM). As well, three thin sections (PSTS) were made from mudstone-rich layers in the Pierre Shale to date detrital zircons associated with the finest fraction of the rock and compare their morphologies and ages to detrital zircons extracted from the bulk sample by crushing.

\section{SEM and LA-ICP-MS Analysis}

Detrital zircon grains were located and identified in the mounts and sections using energy-dispersive X-ray spectroscopy (EDS) and backscattered electron (BSE) image analysis with automated scanning electron microscope (SEM) instruments: an FEI Mineral Liberation Analyzer (MLA) (Fandrich et al., 2007; Sylvester, 2012) for the grain mounts and a TESCAN Integrated Mineralogical Analyzer (TIMA) (Hrstka et al., 2018) for the thin sections. SEM metadata are given in Table DR1. Representative zircon BSE images are shown in Figure DR1.

$\mathrm{U}-\mathrm{Pb}$ age analyses of zircon were made using a Nu Plasma AttoM magnetic sector inductively coupled plasma - mass spectrometry (ICP-MS) coupled to an ESI NWR193UC laser ablation (LA) system consisting of a TwoVol2 ablation chamber and a Coherent Excistar $193 \mathrm{~nm}$ ArF excimer laser. Detrital zircons were chosen for analysis in random fashion to avoid selection bias. Laser spots (20- and 12- $\mu \mathrm{m}$ wide for detrital zircons in mounts and thin sections, respectively) were placed on regions of zircon grains free of fractures, inclusions, or overgrowths, guided by BSE images. For grains approaching $20-\mu \mathrm{m}$ in diameter, it was 
sometimes a challenge to place the $12-\mu \mathrm{m}$ spot without being close to the grain rim, or intersecting small fractures, both of which sometimes have more $\mathrm{Pb}$ loss or common $\mathrm{Pb}$ than fracture-free regions within grains. Also, for zircon grains analyzed directly in thin sections, care was taken not to overlap the laser beam on to the surrounding matrix, which was rich in common $\mathrm{Pb}$ in the case of the mudstones of this study. Careful imaging of the zircon grains in both transmitted and reflected light and measuring grain dimensions prior to laser ablation allowed the choice of laser spot size and positioning to be made most effectively.

Analytical details and instrument parameters are included in Table DR1. Zircon 91500 (Wiedenbeck et al., 2004) was used to correct for mass spectrometer bias on $\mathrm{Pb} / \mathrm{Pb}$ and $\mathrm{U} / \mathrm{Pb}$ isotopic ratios and downhole $\mathrm{U} / \mathrm{Pb}$ isotopic fractionation (Košler et al., 2002) and calculate $\mathrm{U}$ and $\mathrm{Th}$ concentrations from count rates. $\mathrm{Pb} / \mathrm{Pb}$ and $\mathrm{U} / \mathrm{Pb}$ isotopic ages and $\mathrm{U}$ and $\mathrm{Th}$ concentrations were determined using Iolite software (v. 3.63) with the VizualAge DRS (Petrus and Kamber, 2012). Zircon ages were corrected for common $\mathrm{Pb}$ in Iolite using the Andersen (2002) method where the corrected fraction of common $\mathrm{Pb}>0.01$, except where the correction increased the \% discordancy of the grain in the Wetherill Concordia diagram. U-Pb detrital zircon data for the Pierre Shale and Trinidad Sandstone samples are listed in Tables DR2 - DR5. Figure DR2 shows Wetherill Concordia diagrams for detrital zircons in the Pierre Shale and Trinidad Sandstone samples.

Zircon secondary reference materials (SRMs) were analyzed with the detrital zircons from Pierre and Trinidad samples as a check and monitor on data quality: Fish Canyon Tuff zircon $\left({ }^{206} \mathrm{~Pb} /{ }^{238} \mathrm{U}=28.478 \pm 0.024\right.$ (2s) Ma; Schmitz and Bowring, 2001); Plešovice zircon ${ }^{206} \mathrm{~Pb} /{ }^{238} \mathrm{U}=337.16 \pm 0.11$ (2s) Ma; Sláma et al., 2008 recalculated by Horstwood et al., 2016); Temora-2 zircon $\left({ }^{206} \mathrm{~Pb} /{ }^{238} \mathrm{U}=416.78 \pm 0.33\right.$ (2s) Ma; Black et al., 2004); Oracle zircon 
$\left({ }^{207} \mathrm{~Pb} /{ }^{206} \mathrm{~Pb}=1437.05 \pm 0.77(2 \mathrm{~s}) \mathrm{Ma}\right.$; Arizona LaserChron Center website, laserchron.org); Tan Brown zircon $\left({ }^{207} \mathrm{~Pb} /{ }^{206} \mathrm{~Pb}=2512.24 \pm 0.71(2 \mathrm{~s}) \mathrm{Ma}\right.$; Bauer et al., 2020); Owens Gully Diorite (OG1) zircon $\left({ }^{207} \mathrm{~Pb} /{ }^{206} \mathrm{~Pb}=3465.4 \pm 0.6\right.$ (2s) Ma; Stern et al., 2009). U-Pb zircon data for the SRMs analyzed with 20- and 12- $\mu$ m spots are listed in Tables DR6 and DR7 respectively. Figures DR3 and DR4 show Wetherill Concordia diagrams for zircon SRMs analyzed with 20and $12-\mu \mathrm{m}$ spots respectively.

We note that the 12- $\mu \mathrm{m}$ spot sizes produce somewhat older ages ( $2 \mathrm{Ma}$ beyond analytical uncertainty) in Plešovice and Temora2 reference materials than the $20-\mu \mathrm{m}$ spots and their accepted ages. The significance is likely the result of both (1) the presence of somewhat older age domains at small scales intersected more precisely by $12-\mu \mathrm{m}$ than $20-\mu \mathrm{m}$ laser ablation spots and (2) the smaller number of $12 \mu \mathrm{m}$ vs $20 \mu \mathrm{m}$ spot analyses (27 vs 123 for Plešovice, and 22 vs 83 for Temora2), which were insufficient to provide a representative sample both younger and old age domains and yield an overall average within uncertainty of the accepted age. SIMS analyses, which have spot sizes similar to the $12-\mu \mathrm{m}$ laser spots used here, albeit with pit depths of only $1-2 \mu \mathrm{m}$, have identified older domains in both zircon reference materials previously. Sláma et al. (2008) reported that SIMS U-Pb analyses of Plešovice zircon yielded a weighted mean ${ }^{206} \mathrm{~Pb} /{ }^{238} \mathrm{U}$ date of $341.4 \pm 1.3 \mathrm{Ma}$ (61 analyses from 33 individual grains). Figure 11 of

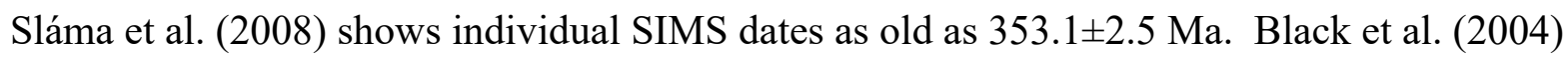
found a weighted mean ${ }^{206} \mathrm{~Pb} /{ }^{238} \mathrm{U}$ SHRIMP date of $418.1 \pm 2.2 \mathrm{Ma}$ for Temora2, with 15 of the 51 analyses giving dates between 430 - $425 \mathrm{Ma}$. The main implication is that, as laser ablation spot sizes continue to decrease, small-scale heterogeneities in zircon grains will be recognized increasingly. 


\section{Disclaimer}

Any use of trade, product, or firm names is for descriptive purposes only and does not imply endorsement by the U.S. Government.

\section{Data Repository References}

Amato, J.M., Mack, G.H., Jonell, T.N., Seager, W.R., and Upchurch, G.R., 2017, Onset of the Laramide orogeny and associated magmatism in southern New Mexico based on U-Pb geochronology: Geological Society of America Bulletin, v. 129, p. 1209-1226, https://doi.org/10.1130/B31629.1.

Andersen, T., 2002. Correction of common lead in U-Pb analyses that do not report $204 \mathrm{~Pb}$. Chemical Geology, 192(1-2), pp.59-79. https://doi.org/10.1016/S0009-2541(02)00195-X

Bauer A.M., Vervoort J.D. and Fisher C.M., 2020. Unraveling the complexity of zircons from the 4.0-2.9 Ga Acasta Gneiss Complex. Geochimica et Cosmochimica Acta, 283, 85-102. https://doi.org/10.1016/j.gca.2020.05.023

Black, L.P., Kamo, S.L., Allen, C.M., Davis, D.W., Aleinikoff, J.N., Valley, J.W., Mundil, R., Campbell, I.H., Korsch, R.J., Williams, I.S. and Foudoulis, C., 2004. Improved 206Pb/238U microprobe geochronology by the monitoring of a trace-element-related matrix effect; SHRIMP, ID-TIMS, ELA-ICP-MS and oxygen isotope documentation for a series of zircon standards. Chemical Geology, 205(1-2), pp.115-140. https://doi.org/10.1016/j.chemgeo.2004.01.003

Clinkscales, C.A., and Lawton, T.F., 2015, Timing of Late Cretaceous shortening and basin development, Little Hatchet Mountains, southwestern New Mexico, USA-Implications for regional Laramide tectonics: Basin Research, v. 27, p. 453-472, https://doi.org/10.1111/bre.12083.

Fandrich, R., Gu, Y., Burrows, D., and Moeller, K., 2007, Modern SEM-based mineral liberation analysis: Int. J. Miner. Process, v. 84, p. 310-320. https://doi.org/10.1016/j.minpro.2006.07.018.

Gonzales, D.A., 2015, New U-Pb zircon and 40Ar/39Ar age constraints on the Late Mesozoic to Cenozoic plutonic record in the Western San Juan Mountains: The Mountain Geologist, v. 52, p. $5-42$.

Horstwood, M. S. A., Košler, J., Gehrels, G., Jackson, S. E., McLean, N. M., Paton, C., Pearson, N. J., Sircombe, K., Sylvester, P., Vermeesch, P., Bowring, J. F., Condon, D. J. and Schoene, B. 2016. Community-derived standards for LA-ICP-MS U-(Th-) Pb geochronology-Uncertainty propagation, age interpretation and data reporting. Geostand. Geoanal. Res., 2016, 40, 311-332. https://doi.org/10.1111/j.1751-908X.2016.00379.x 
Hrstka, T., Gottlieb, P., Skala, R., Breiter, K., and Motl, D., 2018, Automated mineralogy and petrology-applications of TESCAN Integrated Mineral Analyzer (TIMA): Journal of Geosciences, v. 63, p. 47-63, http://dx.doi.org/10.3190/jgeosci.250.

Jaffey, A.H., Flynn, K.F., Glendenin, L.E., Bentley, W.T. and Essling, A.M., 1971. Precision measurement of half-lives and specific activities of U 235 and $U$ 238. Physical Review C, 4(5), p.1889. https://doi.org/10.1103/PhysRevC.4.1889

Košler, J., Fonneland, H., Sylvester, P., Tubrett, M., and Pedersen, R.B., 2002, U-Pb dating of detrital zircons for sediment provenance studies - a comparison of laser ablation ICPMS and SIMS techniques: Chemical Geology, v. 182, p. 605-618, https://doi.org/10.1016/S00092541(01)00341-2.

Markwitz, V., Kirkland, C.L., Mehnert, A., Gessner, K., and Shaw, J., 2017, 3-D

Characterization of Detrital Zircon Grains and its Implications for Fluvial Transport, Mixing, and Preservation Bias: Geochemistry, Geophysics, Geosystems, v. 18, p. 4655-4673, https://doi.org/10.1002/2017GC007278.

Mizer, J.D., 2018, Early Laramide magmatism in southern Arizona; U-Pb geochronology of key igneous units and implications for the timing of regional porphyry copper mineralization [Ph.D. thesis]: Tucson, The University of Arizona, 620 p.

Paton, C., Woodhead, J.D., Hellstrom, J.C., Hergt, J.M., Greig, A. and Maas, R., 2010. Improved laser ablation $\mathrm{U}-\mathrm{Pb}$ zircon geochronology through robust downhole fractionation correction. Geochemistry, Geophysics, Geosystems, 11(3). https://doi.org/10.1029/2009GC002618

Pecha, M.E., Gehrels, G.E., Karlstrom, K.E., Dickinson, W.R., Donahue, M.S., Gonzales, D.A., and Blum, M.D., 2018, Provenance of Cretaceous through Eocene strata of the Four Corners region: Insights from detrital zircons in the San Juan Basin, New Mexico and Colorado: Geosphere, v. 14, p. 785-811, https://doi:10.1130/GES01485.1.

Petrus, J.A. and Kamber, B.S., 2012. VizualAge: A novel approach to laser ablation ICP-MS U$\mathrm{Pb}$ geochronology data reduction. Geostandards and Geoanalytical Research, 36(3), pp.247-270. https://doi.org/10.1111/j.1751-908X.2012.00158.x

Schmitz, M.D. and Bowring, S.A., 2001. U-Pb zircon and titanite systematics of the Fish Canyon Tuff: an assessment of high-precision $\mathrm{U}-\mathrm{Pb}$ geochronology and its application to young volcanic rocks. Geochimica et Cosmochimica Acta, 65(15), pp.2571-2587. https://doi.org/10.1016/S0016-7037(01)00616-0

Sircombe, K.N., and Stern, R.A., 2002, An investigation of artificial biasing in detrital zircon U$\mathrm{Pb}$ geochronology due to magnetic separation in sample preparation: Geochimica et Cosmochimica Acta, v. 66, p. 2379-2397, https://doi.org/10.1016/S0016-7037(02)00839-6.

Sláma, J., and Košler, J., 2012, Effects of sampling and mineral separation on accuracy of detrital zircon studies: Geochemistry, Geophysics, Geosystems, v. 13, 
https://doi.org/10.1029/2012GC004106.

Sláma, J., Košler, J., Condon, D.J., Crowley, J.L., Gerdes, A., Hanchar, J.M., Horstwood, M.S., Morris, G.A., Nasdala, L., Norberg, N. and Schaltegger, U., 2008. Plešovice zircon-a new natural reference material for $\mathrm{U}-\mathrm{Pb}$ and $\mathrm{Hf}$ isotopic microanalysis. Chemical Geology, 249(1-2), pp.1-35. https://doi.org/10.1016/j.chemgeo.2007.11.005

Stern, R.A., Bodorkos, S., Kamo, S.L., Hickman, A.H. and Corfu, F., 2009. Measurement of SIMS instrumental mass fractionation of $\mathrm{Pb}$ isotopes during zircon dating. Geostandards and Geoanalytical Research, 33(2), pp.145-168. https://doi.org/10.1111/j.1751-908X.2009.00023.x

Sylvester, P.J., 2012, Use of the mineral liberation analyzer (MLA) for mineralogical studies of sediments and sedimentary rocks: Mineralogical Association of Canada, Short-Course series, v. 42, p.1-16. https://www.academia.edu/30752354

Wiedenbeck, M.A.P.C., Alle, P., Corfu, F., Griffin, W.L., Meier, M., Oberli, F.V., Quadt, A.V., Roddick, J.C. and Spiegel, W., 1995. Three natural zircon standards for U-Th-Pb, Lu-Hf, trace element and REE analyses. Geostandards Newsletter, 19(1), pp.1-23.

https://doi.org/10.1111/j.1751-908X.1995.tb00147.x

Wiedenbeck, M., Hanchar, J.M., Peck, W.H., Sylvester, P., Valley, J., Whitehouse, M., Kronz, A., Morishita, Y., Nasdala, L., Fiebig, J. and Franchi, I., 2004. Further characterisation of the 91500 zircon crystal. Geostandards and Geoanalytical Research, 28(1), pp.9-39.

https://doi.org/10.1111/j.1751-908X.2004.tb01041.x 
Figure S1. Representative backscattered electron (BSE) Images of detrital zircon in the two major age populations (ca. 71 and $1690 \mathrm{Ma}$ ) of the Pierre Shale and Trinidad Sandstone

Classification of Zircon Grain Morphology Types

Type 1 - Complete, euhedral grain cross sections with oscillatory zoning, suggesting early crystallization free from competing mineral growth

Type 2 - Complete or nearly complete, subhedral grain cross sections, often fractured, with diffuse oscillatory to patchy zoning

Type 3 - Grain cross sections with irregular, embayed crystal faces, suggesting latestage crystallization interstitial to adjacent minerals in the crystalline source rock

Type 4 - Crystal fragments

\section{$71 \pm 3$ Ma Zircon Population}

Pierre Shale Thin Sections

\begin{tabular}{|c|c|c|}
\hline 62-2 (Type 1/2) & 83-1 (Type 2) & 3-1 (Туре 3) \\
\hline $72.4 \pm 2.0 \mathrm{Ma}$ & $69.8 \pm 1.4 \mathrm{Ma}$ & $74.6 \pm 2.9 \mathrm{Ma}$ \\
\hline $\mathrm{Th} / \mathrm{U}=0.76$ & $\mathrm{Th} / \mathrm{U}=1.63$ & $\mathrm{Th} / \mathrm{U}=0.64$ \\
\hline $20 \mu \mathrm{m}$ & $20 \mu \mathrm{m}$ & $20 \mu \mathrm{m}$ \\
\hline 4-1 (Туре 4) & 33-1 (Тype 4) & 34-1 (Тype 4) \\
\hline $73.5 \pm 2.8 \mathrm{Ma}$ & $71.9 \pm 1.5 \mathrm{Ma}$ & $68.4 \pm 1.1 \mathrm{Ma}$ \\
\hline $\mathrm{Th} / \mathrm{U}=4.57$ & $\mathrm{Th} / \mathrm{U}=0.86$ & $\mathrm{Th} / \mathrm{U}=0.57$ \\
\hline $20 \mu \mathrm{m}$ & $20 \mu \mathrm{m}$ & $20 \mu \mathrm{m}$ \\
\hline
\end{tabular}


Pierre Shale Coarse Silt (20-63 $\mu \mathrm{m})$ Grain Mount
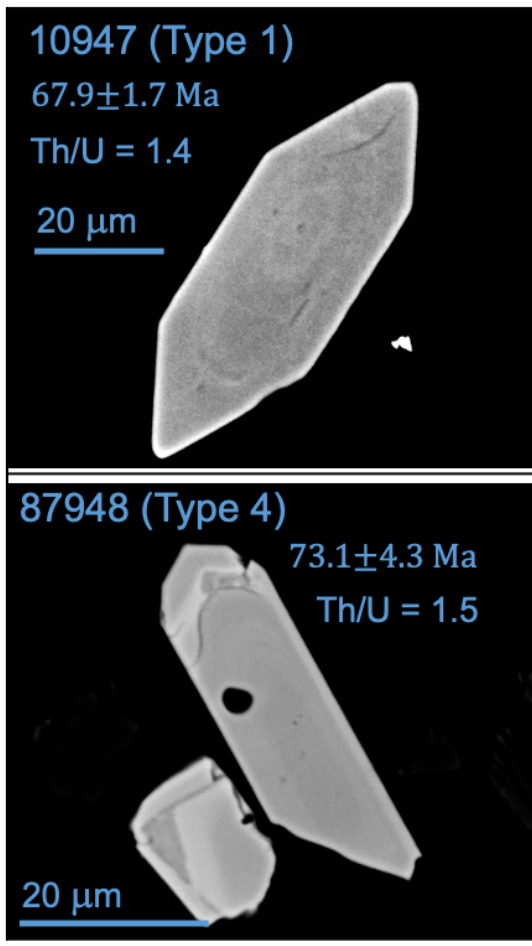

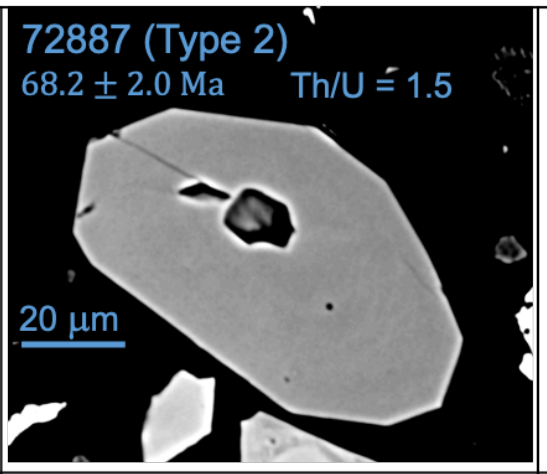

74419 (Type 4 )

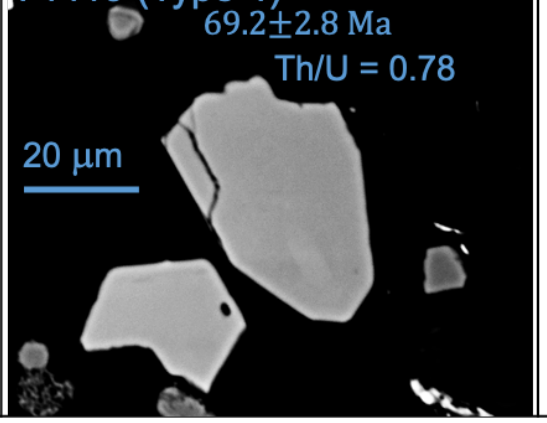

63806 (Type 3)

$70.7 \pm 3.1 \mathrm{Ma}$

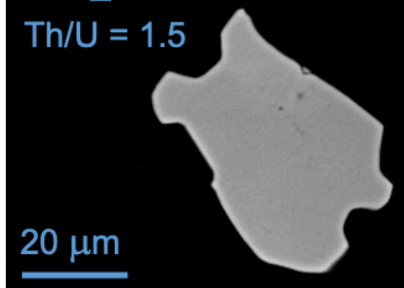

Trinidad Sandstone Coarse Silt $(20-63 \mu \mathrm{m})$ Grain Mount

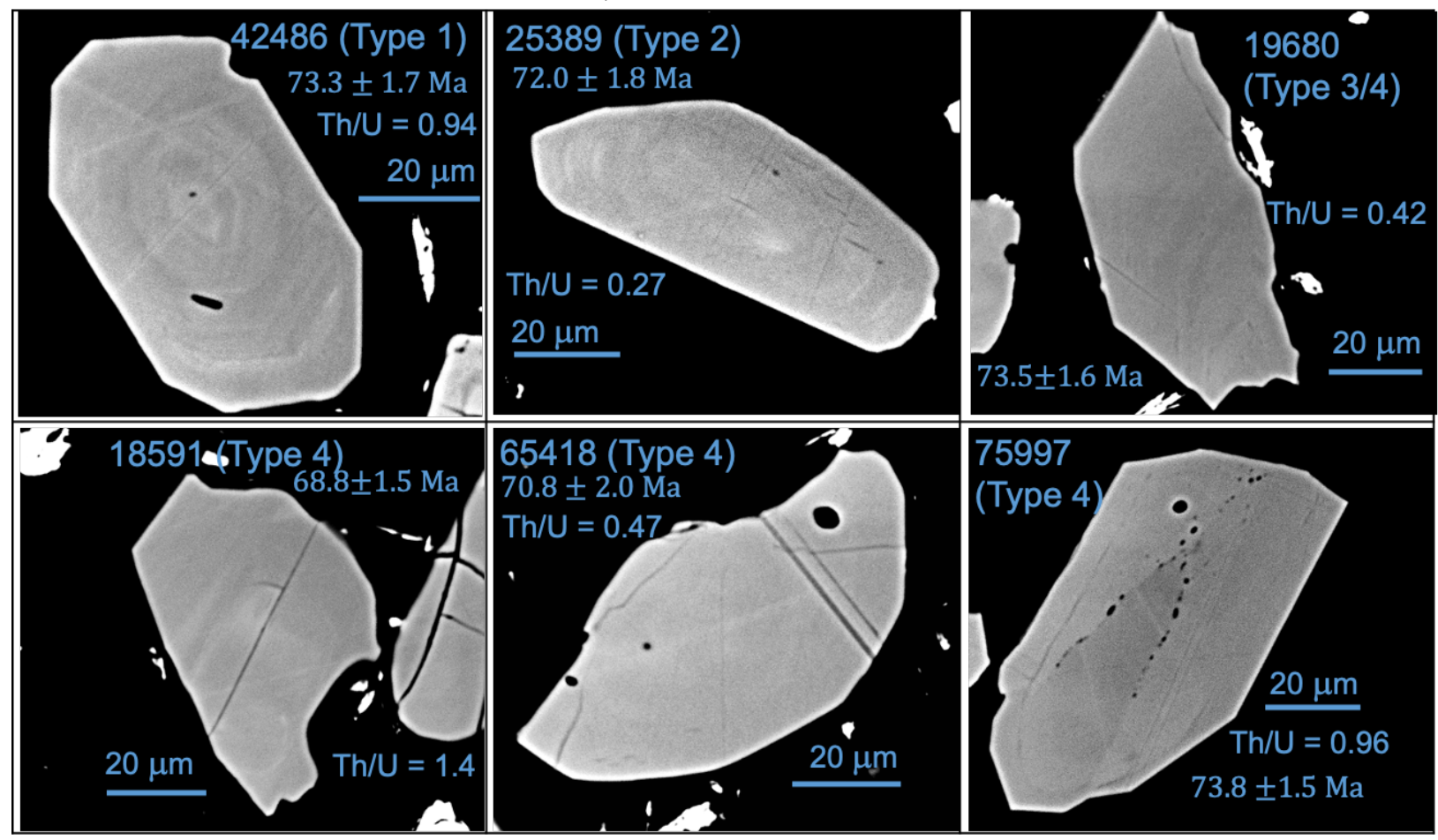


Sylvester, Souders, Liu Geology G49684

Trinidad Sandstone Very Fine Sand (63-125 $\mu \mathrm{m})$ Grain Mount

\begin{tabular}{|c|c|c|}
\hline (Type 1/2) & $\begin{array}{l}4425 \\
\text { (Type 2) } \\
\text { Th/U }=0.39\end{array}$ & $\mathrm{Th} / \mathrm{U}=0.37$ \\
\hline $\begin{array}{l}43400 \quad 67.9 \pm 1.4 \mathrm{Ma} \\
\text { (Type 2) }\end{array}$ & $\begin{array}{l}46503 \text { (Tyре 3) } \\
71.2 \pm 1.2 \mathrm{Ma} \\
20 \mu \mathrm{m}\end{array}$ & $\begin{array}{l}27177 \text { (Type 4) } \\
72.9 \pm 2.0 \mathrm{Ma} \\
\mathrm{Th} / \mathrm{U}=0.36 \\
20 \mu \mathrm{m}\end{array}$ \\
\hline
\end{tabular}

$1690 \pm 15$ Ma Zircon Population

Pierre Shale Thin Sections

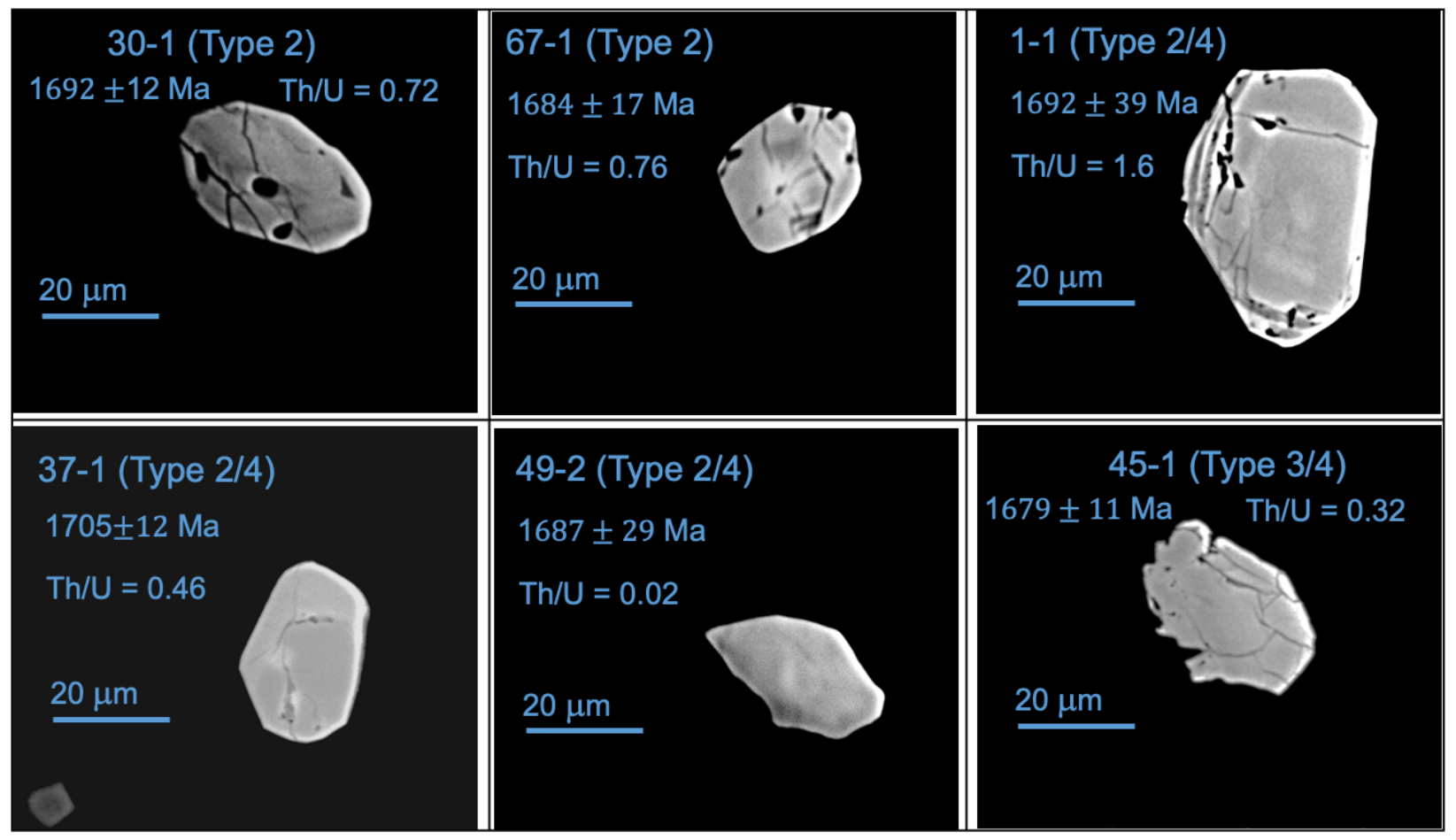


Pierre Shale Coarse Silt $(20-63 \mu \mathrm{m})$ Grain Mount

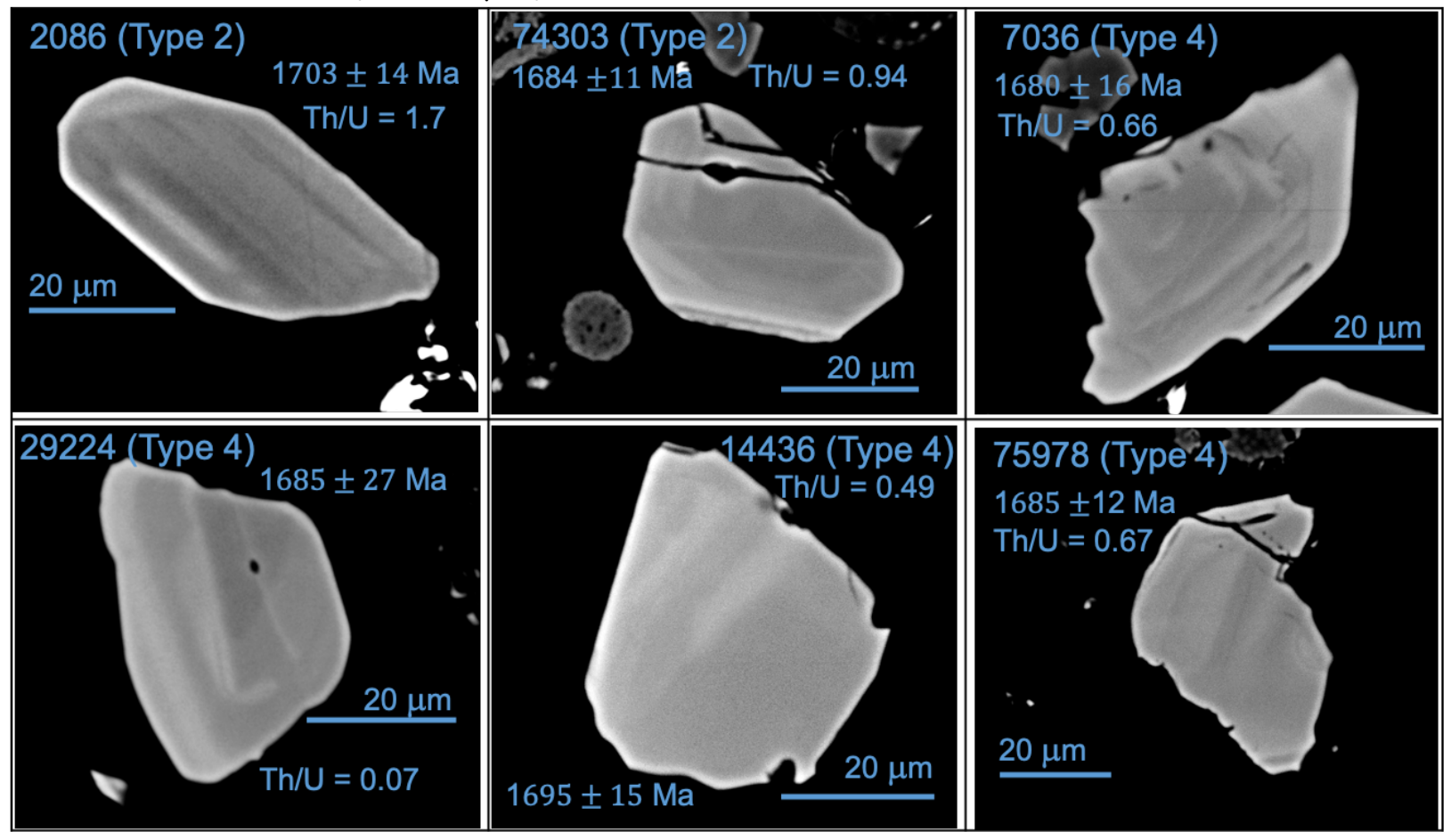

Trinidad Sandstone Coarse Silt $(20-63 \mu \mathrm{m})$ Grain Mount

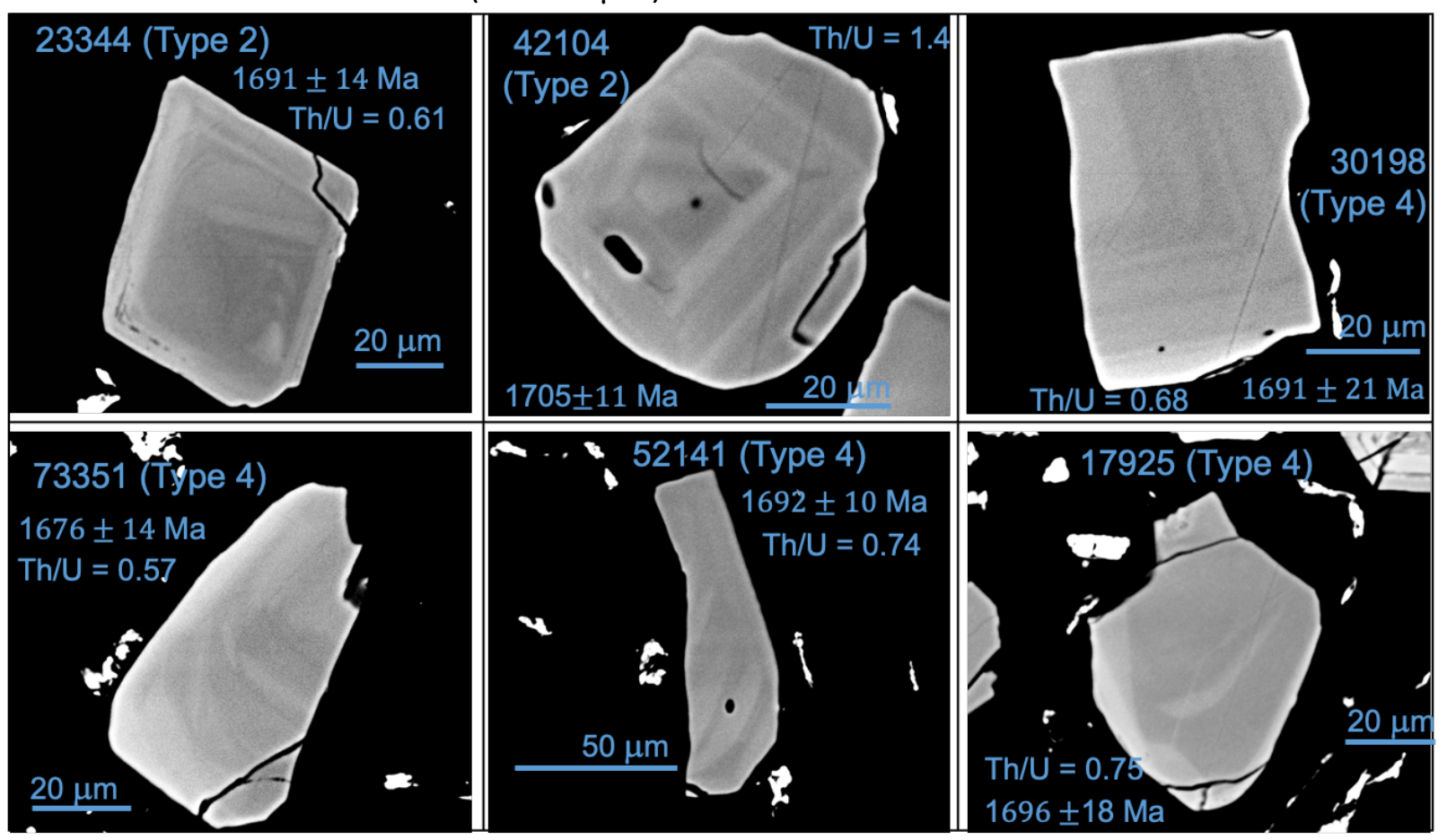


Trinidad Sandstone Very Fine Sand $(63-125 \mu \mathrm{m})$ Grain Mount

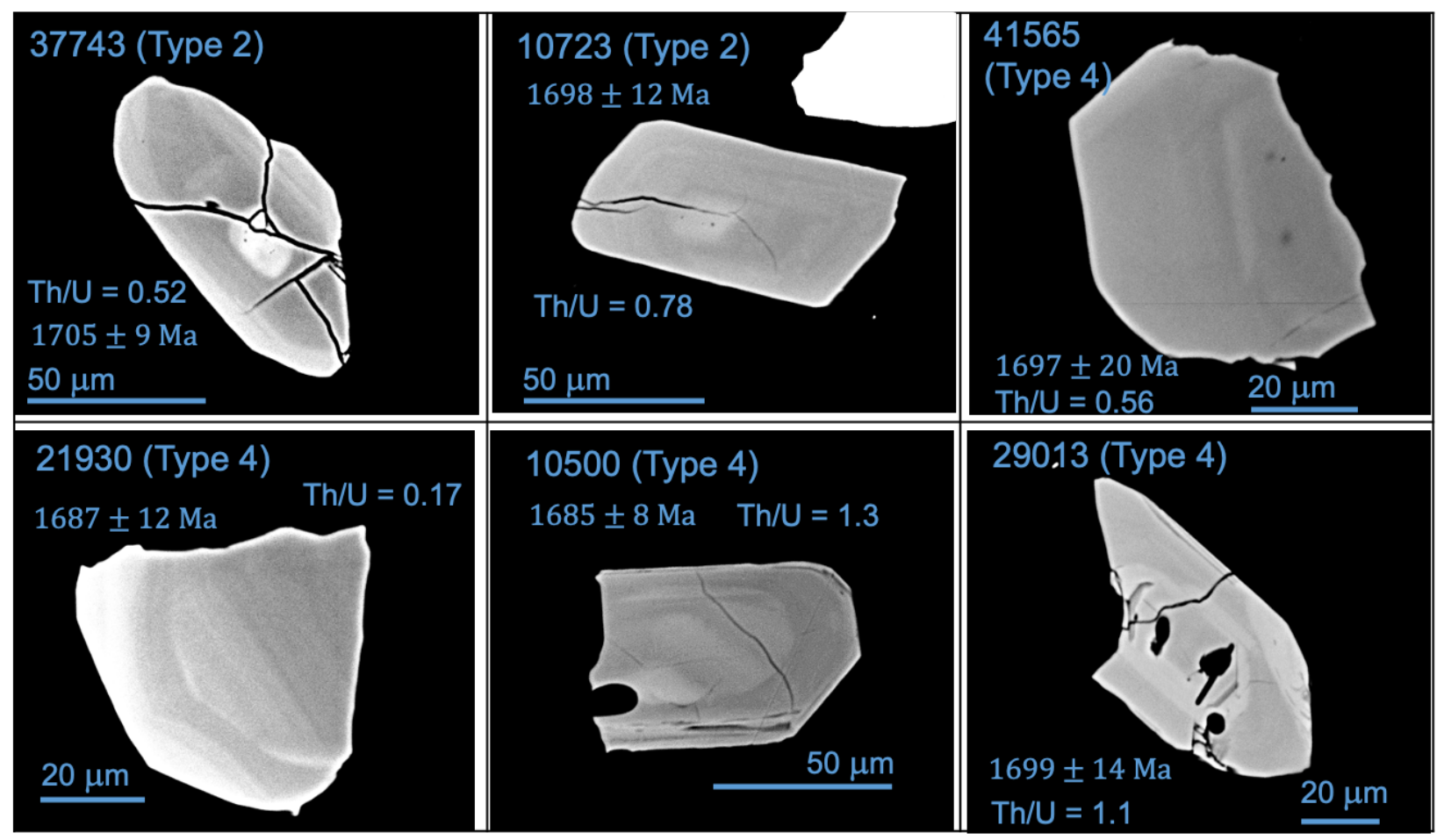


Sylvester, Souders, Liu Geology G49684

Figure S2. Wetherill Concordia diagrams for detrital zircons in Pierre Shale and Trinidad Sandstone (all analyses)
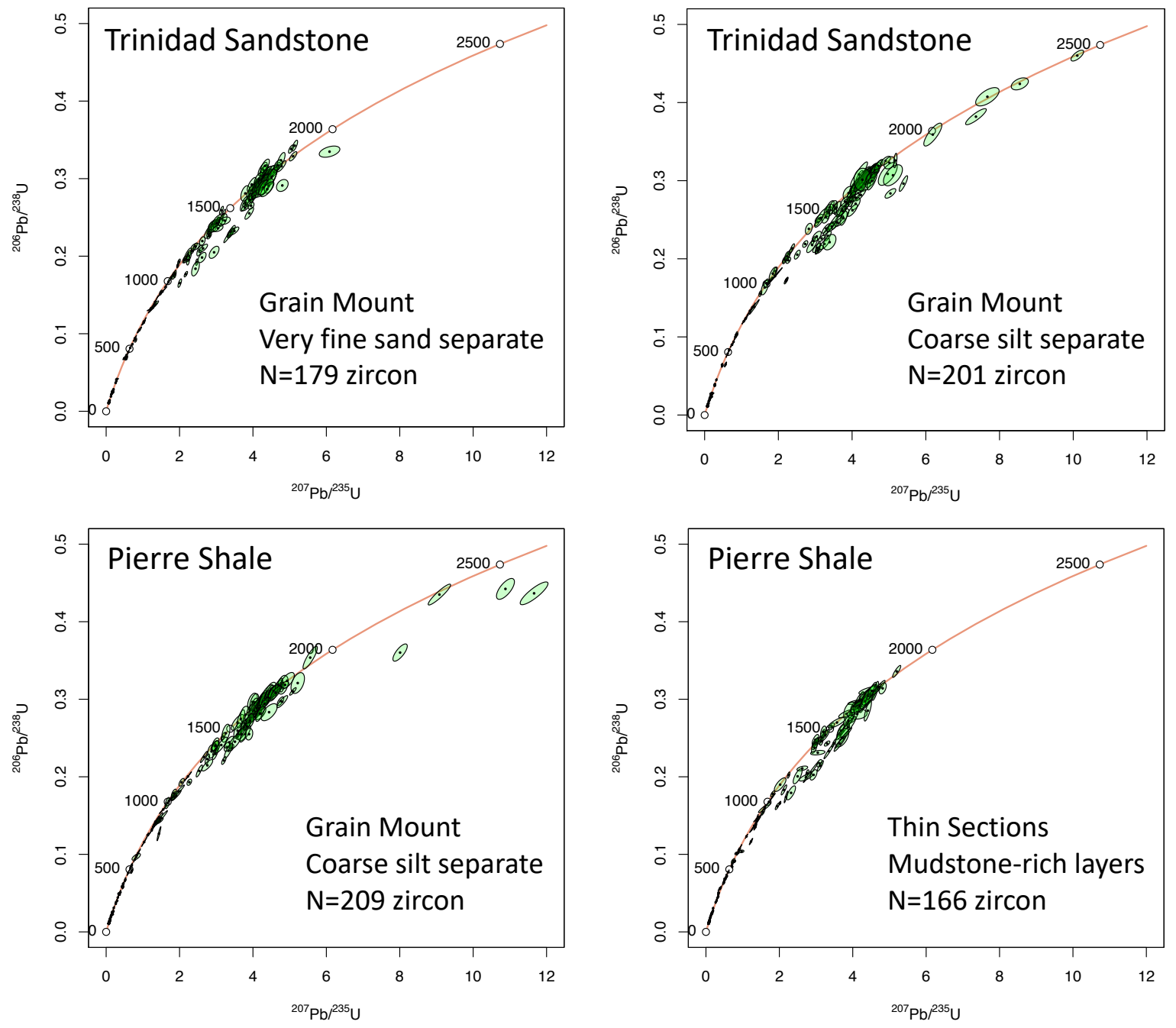
Sylvester, Souders, Liu Geology G49684

Figure S3. Wetherill Concordia diagrams for zircon reference materials - 20-micron spo
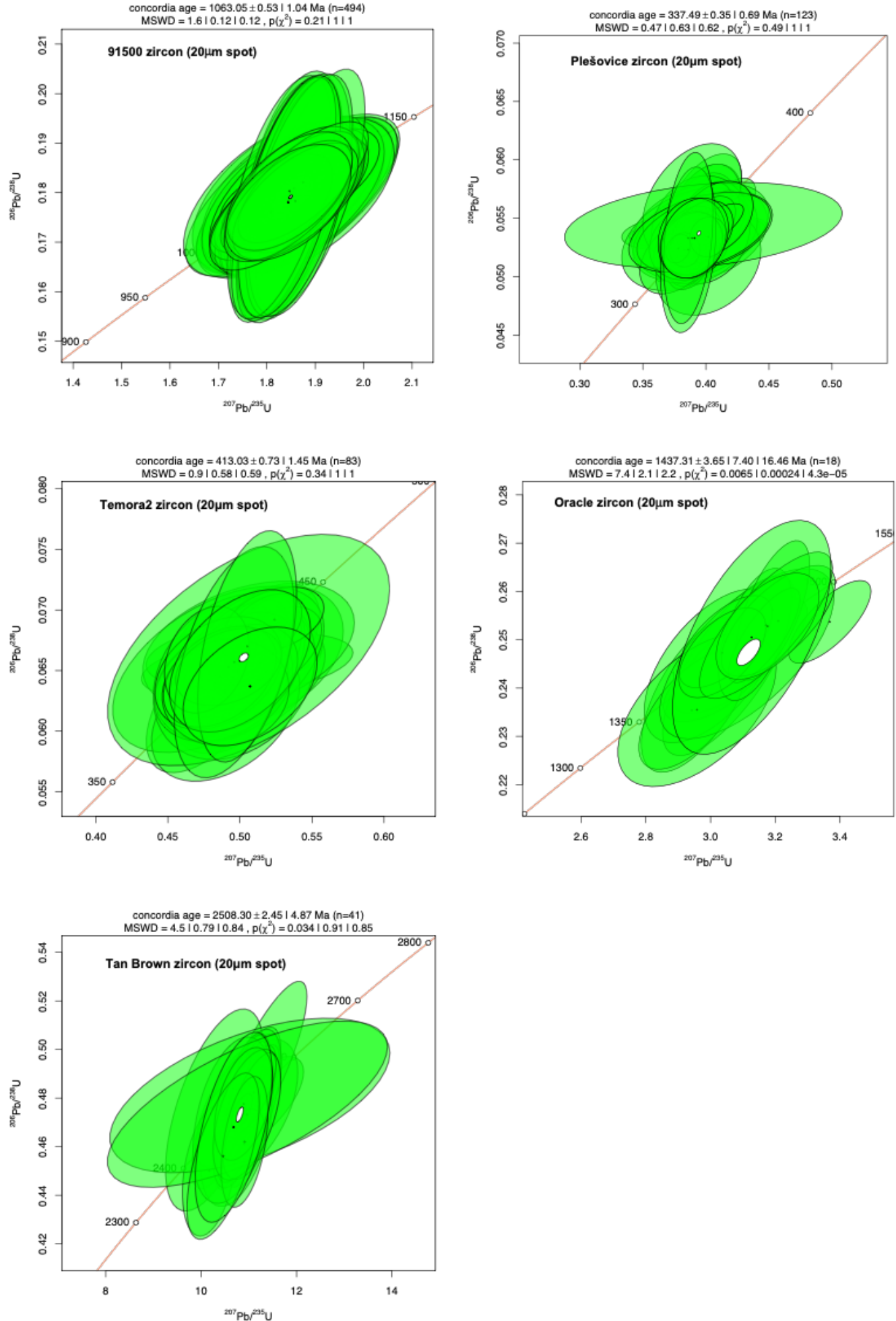
Sylvester, Souders, Liu Geology G49684

Figure S4. Wetherill Concordia diagrams for zircon reference materials - 12-micron spot
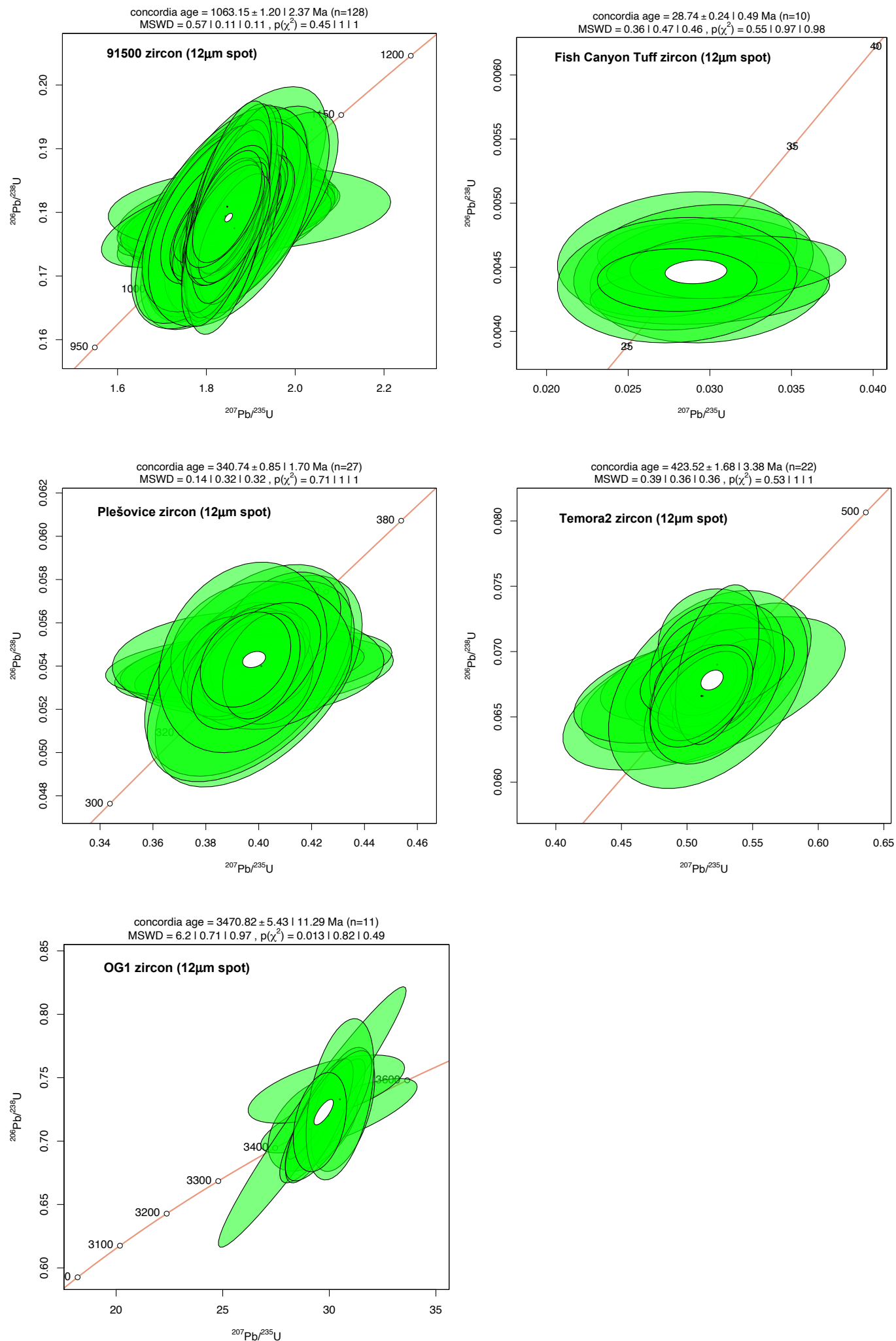
Sylvester, Souders, Liu Geology G49684

Figure S5. Th/U in 1690 Ma Detrital Zircon Grains - Raton Basin

Th/U in $1690 \pm 15$ Ma Detrital Zircon Grains - Raton Basin

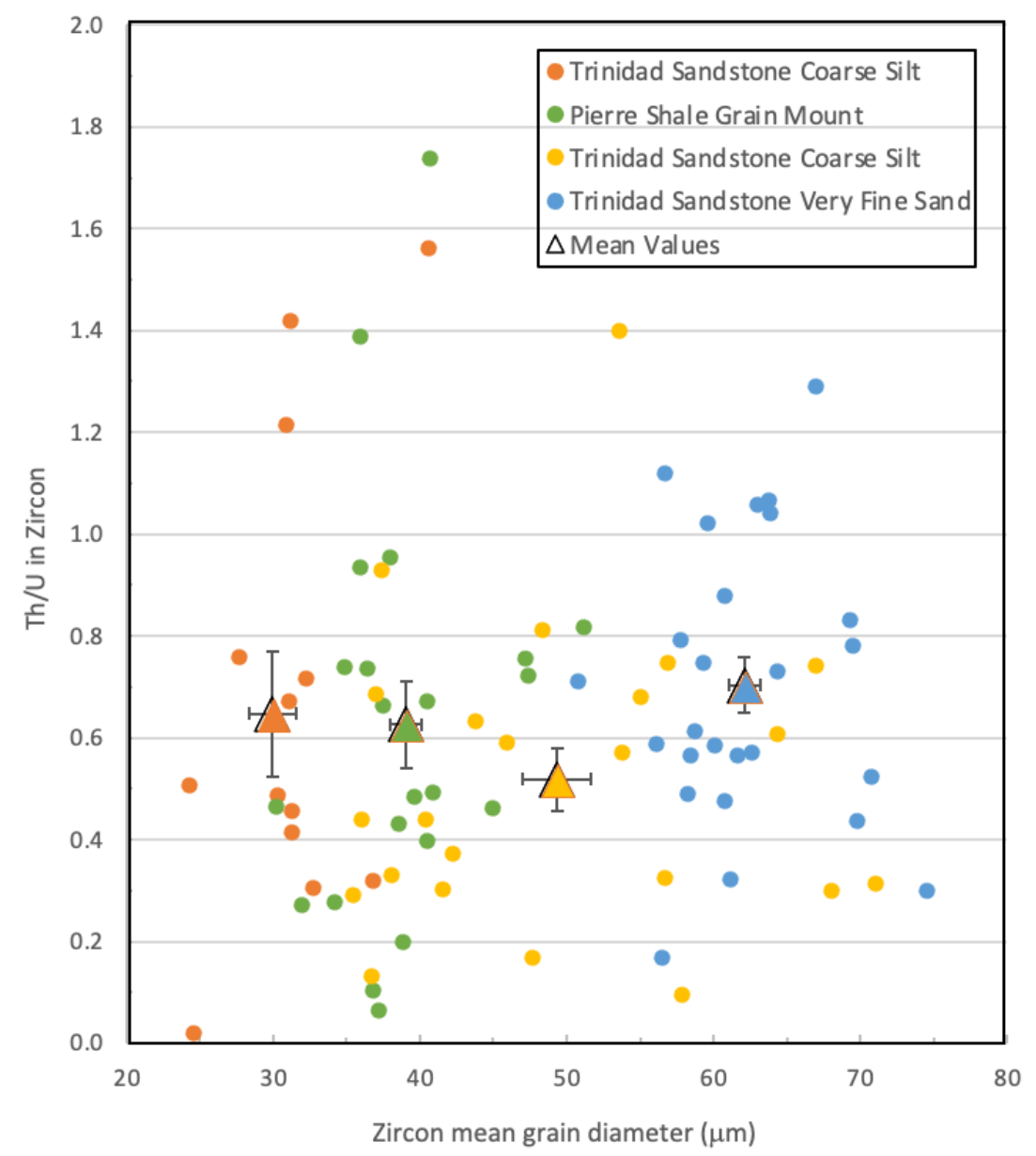


Table S1. Analytical method metadata for scanning electron microscope imaging and LAICP-MS U-Pb geochronology of zircon

\begin{tabular}{|c|c|}
\hline $\begin{array}{l}\text { Laboratory and Sample } \\
\text { Preparation }\end{array}$ & \\
\hline Laboratory name & Mineral Isotope Laser Laboratory (MILL), Texas Tech University \\
\hline Sample type/mineral & Detrital zircons \\
\hline Sample preparation & $\begin{array}{l}\text { Conventional crushing and heavy liquid mineral separation, } 25-\mathrm{mm} \\
\text { epoxy resin mount, } 1-\mu \mathrm{m} \text { polish to finish } \\
\text { Offcuts made into polished thin sections }\end{array}$ \\
\hline $\begin{array}{l}\text { Scanning Electron } \\
\text { Microscope (SEM) } \\
\text { Imaging }\end{array}$ & $\begin{array}{l}\text { TIMA (TESCAN Integrated Mineral Analyzer): TESCAN-VEGA-3 } \\
\text { SEM, BSE-EDX, HV: } 25.0 \mathrm{kV} \text {, WD: } 14.8-15.1 \mathrm{~mm} \\
\text { MLA (Mineral Liberation Analyzer): FEI Quanta } 400 \text { SEM, BSE- } \\
\text { EDX, HV: } 25.0 \mathrm{kV} \text {, WD: } 11.9-12.3 \mathrm{~mm}\end{array}$ \\
\hline $\begin{array}{l}\text { Laser ablation } \\
\text { system }\end{array}$ & \\
\hline Make, Model and type & ESI/New Wave Research, NWR193UC ArF excimer laser \\
\hline Ablation cell & TwoVol2 two-volume ablation chamber \\
\hline $\begin{array}{l}\text { Laser wavelength } \\
(\mathrm{nm})\end{array}$ & $193 \mathrm{~nm}$ \\
\hline Pulse width (ns) & $5 \mathrm{~ns}$ \\
\hline Fluence $\left(\mathrm{J} \mathrm{cm}^{-2}\right)$ & $2.5 \mathrm{~J} \mathrm{~cm}^{-2} / 4.25 \mathrm{~J} \mathrm{~cm}^{-2}$ \\
\hline Repetition rate $(\mathrm{Hz})$ & $8 \mathrm{~Hz}$ \\
\hline Ablation duration (s) & $30 \mathrm{~s}$ \\
\hline $\begin{array}{l}\text { Spot diameter }(\mu \mathrm{m}) \\
\text { nominal/actual }\end{array}$ & $20 \mu \mathrm{m} / 12 \mu \mathrm{m}$ \\
\hline $\begin{array}{l}\text { Sampling mode / } \\
\text { pattern }\end{array}$ & Static spot ablation \\
\hline Carrier gas & $\begin{array}{l}100 \% \text { He in the cell, Ar make-up gas combined using a Y-piece } \\
75 \% \text { along the sample transport line to the torch. }\end{array}$ \\
\hline $\begin{array}{l}\text { Cell carrier gas flow } \\
\left(\mathrm{He}, 1 \mathrm{~min}^{-1}\right)\end{array}$ & $0.775-0.8501 \mathrm{~min}^{-1}$ \\
\hline \multicolumn{2}{|l|}{ ICP-MS Instrument } \\
\hline Make, Model and type & $\mathrm{Nu}$ Instruments, $\mathrm{Nu}$ AttoM ICP-MS \\
\hline Sample introduction & Laser Ablation \\
\hline RF power $(\mathrm{W})$ & $1300 \mathrm{~W}$ \\
\hline Ar gas flows $\left(1 \mathrm{~min}^{-1}\right)$ & $\begin{array}{l}\text { Cool gas }(\mathrm{Ar})=13.01 \mathrm{~min}^{-1} \\
\text { Aux gas }(\mathrm{Ar})=0.7-0.951 \mathrm{~min}^{-1} \\
\text { Ar make gas }(\mathrm{Ar})=0.65-0.851 \mathrm{~min}^{-1}\end{array}$ \\
\hline
\end{tabular}




\begin{tabular}{|c|c|}
\hline Detection system & MasCom Electron Multiplier \\
\hline Masses measured & $202,204,206,207,208,232,235,238$ \\
\hline $\begin{array}{l}\text { Integration time per } \\
\text { peak/dwell times (ms) }\end{array}$ & $200 \mu \mathrm{s}$ for each isotope except $400 \mu \mathrm{s} 206,1 \mathrm{~ms} 207,2 \mathrm{~ms} 235$ \\
\hline $\begin{array}{l}\text { Total integration time } \\
\text { per output data point (s) }\end{array}$ & $0.1984 \mathrm{~s}$ \\
\hline $\begin{array}{l}\text { Analysis mode/ Detection } \\
\text { mode }\end{array}$ & Deflector jump/Pulse counting \\
\hline IC Dead time (ns) & $9.2 \mathrm{~ns}$ \\
\hline \multicolumn{2}{|l|}{ Data Processing } \\
\hline Calibration strategy & $\begin{array}{l}91500 \text { zircon used as primary reference material, Plešovice, } \\
\text { Temora2, Oracle, Tan Brown, OG1 and Fish Canyon Tuff zircons } \\
\text { used as secondaries/validation }\end{array}$ \\
\hline $\begin{array}{l}\text { Reference material } \\
\text { (zircon) information }\end{array}$ & $\begin{array}{l}91500 \text { (Wiedenbeck et al. 1995) } \\
\text { Plešovice (Sláma et al. 2008) } \\
\text { Temora2 (Black et al., 2004) } \\
\text { Oracle (Arizona LaserChron Center website, laserchron.org) } \\
\text { Tan Brown (Bauer et al., 2020) } \\
\text { OG1 (Stern et al., 2009) } \\
\text { Fish Canyon Tuff (Schmitz and Bowring, 2001) }\end{array}$ \\
\hline $\begin{array}{l}\text { Data processing } \\
\text { package used / } \\
\text { Correction for LIEF }\end{array}$ & $\begin{array}{l}\text { Iolite (v3.63) and VizualAge DRS (Petrus and Kamber 2012) } \\
\text { software for data normalization, uncertainty propagation and age } \\
\text { calculation. LIEF correction modeled using Exponential model in } \\
\text { Iolite for } 91500 \text { zircon. Assumes reference material and samples } \\
\text { behave identically. Ages are quoted at } 2 s \text { absolute. }\end{array}$ \\
\hline $\begin{array}{l}\text { Common- } \mathrm{Pb} \text { correction, } \\
\text { composition and } \\
\text { uncertainty }\end{array}$ & $\begin{array}{l}\text { For zircons with high common } \mathrm{Pb} \text {, ages are corrected with the } \\
\text { Andersen (2002) method }\end{array}$ \\
\hline $\begin{array}{l}\text { Quality control / } \\
\text { Validation / Concordia } \\
\text { Ages }\end{array}$ & $\begin{array}{l}\text { Plešovice }(20 \mu \mathrm{m})-337.5 \pm 0.7(2 s, \mathrm{MSWD}=0.5, \mathrm{n}=123) \\
\text { Temora-2 }(20 \mu \mathrm{m})-413.0 \pm 1.4(2 s, \mathrm{MSWD}=0.9, \mathrm{n}=83) \\
\text { Oracle }(20 \mu \mathrm{m})-1437.3 \pm 7.4(2 s, \mathrm{MSWD}=7.4, \mathrm{n}=18) \\
\text { Tan Brown }(20 \mu \mathrm{m})-2508.3 \pm 4.9(2 s, \mathrm{MSWD}=4.5, \mathrm{n}=41) \\
\text { Fish Canyon Tuff }(12 \mu \mathrm{m})-28.74 \pm 0.49(2 s, \mathrm{MSWD}=0.4, \mathrm{n}=10) \\
\text { Plešovice }(12 \mu \mathrm{m})-340.7 \pm 1.7(2 s, \mathrm{MSWD}=0.14, \mathrm{n}=27) \\
\text { Temora-2 }(12 \mu \mathrm{m})-423.5 \pm 3.4(2 s, \mathrm{MSWD}=0.4, \mathrm{n}=22) \\
\text { OG1 }(12 \mu \mathrm{m})-3471 \pm 11(2 s, \mathrm{MSWD}=6.2, \mathrm{n}=11)\end{array}$ \\
\hline
\end{tabular}

